ppi $201502 Z U 4645$

Esta publicación cientifica en formato digital es continuidad de la revista impresa ISSN-Versión Impresa 0798-1406 / ISSN-Versión on line 2542-3185Depósito legal pp

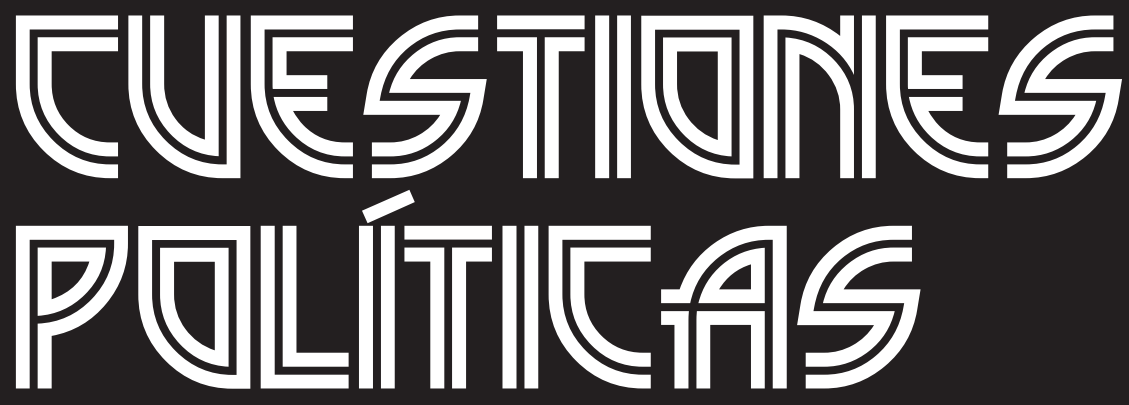

Instituto de Estudios Políticos y Derecho Público "Dr. Humberto J. La Roche' de la Facultad de Ciencias Jurídicas y Políticas de la Universidad del Zulia Maracaibo, Venezuela
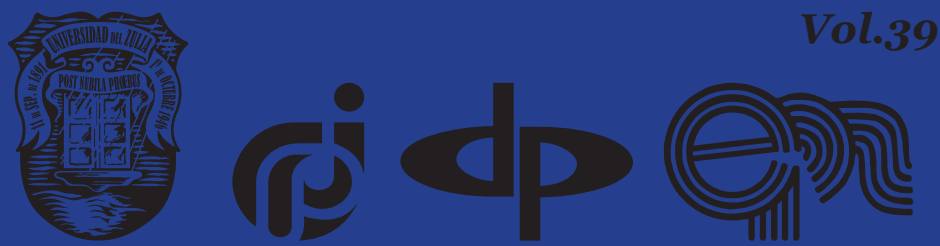


\title{
Rethinking the category of organic intellectual of/by Antonio Gramsci in today's world
}

\author{
DOI: https://doi.org/10.46398/cuestpol.3968.17
}

\author{
Anatolii P. Getman * \\ Danilyan Oleg $\mathbf{G}$. ** \\ Magda Julissa Rojas-Bahamón *** \\ Diego Felipe Arbeláez-Campillo **** \\ Olexandra's Ptashnyk-Serediuk *****
}

\section{Abstract}

The attempt to assess the essential functions and aspects of the intellectual establishment in the modern and contemporary world occupies a prominent place in the social sciences and in the political philosophy of the 2oth century. Antonio Gramsci was undoubtedly one of the philosophers who made the most heuristic and hermeneutical contributions, from his revisionist Marxist perspective, to understand intellectuals as leading actors and active political subjects, situated in the dilemma of favoring the preservation of the established order, in the case of traditional intellectuals, or in promoting their radical transformation as a program of action of the so-called organic intellectuals, who dedicate themselves at all times to interpret the needs and aspirations of justice and equity of the time and social space of which they are part, to endow it with concrete political content. Consequently, the objective of this scientific article is to examine the role of the critical intellectual with social commitment in the current complex context, marked by the systemic crisis of the current world order. Methodologically speaking, the document presented here was developed through dialectical hermeneutics and the documentary research

* Doctor of Legal Sciences, Professor, Rector of Yaroslav Mudryi National Law University, Ukraine. ORCID ID: https://orcid.org/oooo-0oo2-1987-2760. Email: apgetman@nulau.edu.ua

** Doctor of Philosophical Sciences, Professor, Head of the Department of Philosophy of Yaroslav Mudryi National Law University. ORCID ID: https://orcid.org/oooo-ooo1-5308-4664. Email: odana@i.ua

*** PhD. Educación y cultura ambiental. Docente IE Jorge Eliecer Gaitán, Universidad de la Amazonia, Colombia. ORCID ID: https://orcid.org/oooo-00o3-4882-1476. Email: mjulissa@gmail.com

**** Grupo de investigación Lenguajes, representaciones y Educación, Universidad de la Amazonia, Colombia. ORCID ID: https://orcid.org/oooo-0002-9041-9563. Email: dfaca@hotmail.com

***** Candidate of Sociological Sciences, Associate Professor of the Department of Social and Humanitarian Disciplines of the Precarpathian Department of the National Academy of Internal Affairs. ORCID ID: https://orcid.org/oooo-0002-1529-2443. Email: ops78@ukr.net 
Anatolii P. Getman, Danilyan Oleg G., Magda Julissa Rojas-Bahamón, Diego Felipe ArbeláezCampillo y Olexandra's Ptashnyk-Serediuk

technique. The findings obtained allow us to conclude that critical thinking is key to revitalizing democracies.

Keywords: organic intellectual; traditional intellectual; Antonio Gramsci; critical thinking; systemic crisis of the world order.

\section{Repensando la categoría de Intelectual Orgánico de Antonio Gramsci en el Mundo de Hoy}

\section{Resumen}

El intento por valorar las funciones y aspectos esenciales del estamento intelectual en el mundo moderno y contemporáneo ocupa un lugar prominente en las ciencias sociales y en la filosofía política del siglo XX. Antonio Gramsci fue sin duda uno de los filósofos que más aportes heurísticos y hermenéuticos efectúo, desde su perspectiva marxista revisionista, para comprender a los intelectuales como actores protagónicos y sujetos políticos activos, situados en la disyuntiva de propender a la conservación del orden establecido, en el caso de los intelectuales tradicionales, o en impulsar su transformación radical como programa de acción de los llamados intelectuales orgánicos, que se dedican en cada momento a interpretar las necesidades y aspiraciones de justicia y equidad del tiempo y espacio social del que forman parte, para dotarlo de contenido político concreto. En consecuencia, el objetivo de este artículo científico consiste en examinar la función del intelectual crítico con compromiso social en el complejo contexto actual, signado por la crisis sistémica del orden mundial vigente. Metodológicamente hablando el documento que aquí se presenta se desarrolló mediante la hermenéutica dialéctica y la técnica de investigación documental. Los hallazgos recabados permiten concluir que el pensamiento crítico es clave para revitalizar las democracias.

Palabras clave: intelectual orgánico, intelectual tradicional; Antonio Gramsci; pensamiento crítico; crisis sistémica del orden mundial.

\section{Introduction}

Lato sensu for intellectuals we want to cover, following the contributions of Mansilla (2002), the specialists, technical-organizational of the public administration, in areas as diverse as the economy, the human and social sciences, university professors, public policy makers, planners, philosophers, writers and social communicators, among others. "But 
this term is usually designated in a more restricted way to" independent "producers of spiritual values, to creators of meaning who take advantage of the most advanced knowledge of the international cultural community..." (Mansilla, 2002: 430).

The notion of intellectuals is a broad concept in which a set of different activities such as science, culture, literature, art and philosophy, among others, are delimited, in which, beyond their particularities, development creative and cognitive processes as a trade or profession by people who are, strictly speaking, responsible for developing and socializing the ideas and reflections that set the standard, materially and symbolically, in the public opinion of a society that grants them moral-scholarly authority or, simply, to act as specialists in the different human activities in the face of the production of goods and services.

In the case of intellectuals in political activity, their social impact is much greater, without ignoring that even approaches that in principle do not have a concrete political foundation, could ultimately have biased political and ideological uses, as happened, for example, with the theory of evolution of Charles Darwin, which would degenerate into social Darwinism to justify racist policies of social exclusion that sought the predominance of certain ethnic groups over others.

From this perspective, intellectuals have at the time a very important connection with the socio-political realities of which they are part and, therefore, their published work has repercussions, according to their particular bias, either in the preservation of the established order, in the in the case of the so-called traditional intellectuals, or, in promoting their transformation as a program of action, in the case of the so-called organic intellectuals, who, according to Gramsci (1967), are dedicated to interpreting at all times the needs and aspirations of justice and fairness of time and the social space of which they are part, to provide it with concrete political content contrary to the hegemonic interests of the historical bloc ${ }^{6}$ (Portelli, 1978).

The objective of this scientific article is to examine the role of the critical intellectual with social commitment in the current complex context, marked by the systemic crisis of the current world order (Villasmil, 2020;

6 Simplifying things, in Antonio Gramsci's terminology the historical block is the symmetry that exists between the infrastructure, that is, for Marxism, the totality of the productive forces that in a time and space determine the existing means and modes of production., with the superstructure, or more specifically with the culture, the law and the general episteme of a model of society, to respond at all times to the hegemonic project that identifies a dominant class in the exercise of power and justifies or tries to justify and rationalize, in social representations, their domination, symbolic capital and particular privileges as something natural and never as a historical anomaly that benefits some and harms many others. For more information in this regard, we recommend consulting the Gramsci texts that appear at the end in the reference index or the link: https://kmarx.wordpress.com/2012/11/20/ el-intelectual-organico-en-gramsci -an approximation/. 
Anatolii P. Getman, Danilyan Oleg G., Magda Julissa Rojas-Bahamón, Diego Felipe ArbeláezCampillo y Olexandra's Ptashnyk-Serediuk

276

Rethinking the category of organic intellectual of/by Antonio Gramsci in today's world

Parra, 2020; Arbeláez-Campillo et al, 2019; Arbeláez-Campillo and Rojas-Bahamón, 2020), all within the framework of an inter-ideological political and philosophical debate that seeks to rethink - in the heat of the requirements and challenges imposed by the 21st century agenda - some theories, thinkers and works that, As in the case of certain proposals by Antonio Gramsci (1891-1937), they continue to have an unusual validity beyond the differences of time. As might be expected due to the nature of the subject, methodologically speaking the document presented here was developed through dialectical hermeneutics and the documentary research technique, from a holistic and interdisciplinary vision of political thought.

The work is divided into four particular sections, namely: 1) revised literature, which accounts for the substrate of classical or neoclassical works that, in primary and secondary sources, directly or indirectly address the central role played by the subject of the intellectuals in the work of this remarkable Italian thinker; 2) methodology, section where the interpretive processes used in the organization and reading of the sources collected in the form of printed documents in physical and digital format are succinctly exposed; 3) organic intellectuals in today's world, where the political and ideological implications that in theory and in reality impose the practices of critical, associative and innovative thinking are discussed. Finally, the final reflections and the main research findings are presented in the conclusions section.

\section{Literature reviewed}

Next, a selective bibliographic balance is made of what, in our opinion, are the main works on the broad and advanced philosophical project of Antonio Gramsci, either due to the depth of his investigation, the appropriate handling of primary sources or for the consistency of his ideas. This documentary archiving was carried out as a condition of possibility to determine the contributions or limitations of the selected anthology that, in theory, would correct this investigation. It should be clarified that the scientific article presented here focused almost exclusively on the question of intellectuals and, furthermore, that the work is subsidiary in its main lines of argument of the imprint of these works with which it dialogues in a hermeneutic and intertextual.

Gramsci is a thinker situated in the rigors of Italy in the second decade of the 20th century (Fiori, 1976); Consequently, he experienced firsthand the transformation of the nineteenth-century world order that would mark the beginning of the end of the British, Ottoman, Tsarist Russia and, ultimately, the construction of the USSR. His particular reading of Marxism allows him to rethink the role of culture, the State and intellectuals in the new order of things that was being born dialectically at the time, from the 
deep conviction that the processes of domination develop mainly in the systems of beliefs - ideology and superstructure - that serve as the basis for the law, the institutions of power and all historically existing forms of state and government, since it is not possible for the ruling classes to govern solely through coercive devices of social control, which is why which appeal to the legitimation of their hegemony in the collective imaginary (DíazSalazar, 1991).

For Bobbio (1991), roughly the political theory of Gramsci that emerges from his fragmented thought due to the difficulties of his life history, opposes the notions of civil society and the State. Unlike the tradition implemented by contractarians, conditioned by the enlightened liberal tradition, the State is now not the highest incarnation of the social contract to definitively overcome the state of nature, characterized in its course by the irrationality of a type of relationship intersubjective where the will of the strongest predominates at each moment. The Gramsci of the prison notebooks:

(...) Belongs to this new history in which, to summarize, the State is not an end in itself, but an apparatus, an instrument; He is the representative of interests not universal, but particular; It is not a prevailing entity over the underlying society, but is conditioned by it and, therefore, subordinate to it, is not a permanent institution, but a transitory one, destined to disappear with the transformation of the underlying society (Bobbio, 1991: 340).

For its part, civil society would be the social dimension that is not directly controlled by the State, as a neural point of the hegemonic political system and the constituted powers, in the words of Portelli: "Civil society is the true home and scene of history... civil society encompasses the entire material exchange of individuals in a given phase of development of the productive forces" (1978: 15).

Without wishing to comment on the limitations or weaknesses of this conception of civil society, two preliminary conclusions quickly emerge: on the one hand, the State is not the last stage in the history of the forms of political organization, hence the Marxists postulate the supposed need for its dissolution because it is an instrument of domination that represents the particular interests of the elites in the exercise of power; on the other hand, organic intellectuals set themselves up as a sort of lucid conscience of the revolutionary social forces that bet on the liberation of all forms of exploitation.

According to Buci-Glucksmann (1978), the distinguished Italian thinker was undoubtedly a revisionist Marxist, while his vision of dialectical materialism as a politically situated method of study to interpret the ultimate meaning of the historical movement of human societies and 
Anatolii P. Getman, Danilyan Oleg G., Magda Julissa Rojas-Bahamón, Diego Felipe ArbeláezCampillo y Olexandra's Ptashnyk-Serediuk

to build theoretical-practical tools in favor of the definitive liberation of the subordinate groups. Therefore, his work represented a kind of Western alternative to a too economistic or too Leninist Marxism that, by concentrating on the study of social systems and structures, underestimated the analysis of individuals and particular groups that, like intellectuals, movements Students or political parties play a role in the construction, maintenance or destruction of the superstructure and its historical block.

In this order of ideas, the construction of a specific socio-economic formation such as slavery, feudalism or capitalism not only reflects the type of development of the productive forces in their different stages and moments, but also the project of power that specialized intellectuals They make to justify the interests of the ruling classes and make the burden of domination more bearable, hence, since the origins of the first human civilizations, religions have played a leading role in the divinization of the actors and factors of power, to inhibit a priori any form of resistance or subversion of the established order (Gramsci, 1967; 1986). In any case, it is clear that the infrastructure and the superstructure never emerge by chance or providence, but by the deliberate materialization of hegemonic interests, rationalized by theories, ideologies and all kinds of power discourses.

These postulates explain the centrality of intellectuals in Gramsci's thought and its dichotomous organization in the categories of traditional intellectuals vs. organic intellectuals. In the first case, according to Dussel (2001), organic intellectuals have the maximum purpose of collaborating, according to the status and role in which they are located, in the construction of a critical philosophy, that is, a systematic approach based on empirical evidence. that presents the prevailing system of domination as an intolerable reality that can and should be transformed, for which purpose they empathically place themselves in the place of the victims, while proposing viable alternatives to radically improve their historical situation and living conditions in general.

In stark contrast, traditional intellectuals or, according to Dussel (2001), intellectuals functional to the system do not have any ethical conflict with the result of the prevailing order of things, either because they do not have historical and political awareness of reality, think about this point , in the fundamental engineers or technicians for the development of industrial activity in the different productive proceedings that fall into the category of intellectuals or; because they are comfortable with their privileges as a high-level workforce, or; simply because, as traditional intellectuals, who may have been organic at one stage of their life, ideologically assume that the present moment is the obligatory product of historical evolution, insofar as the system of relationships that exists between people, including Dramatic experiences of injustice and inequality represent the best way to divide the valuable goods that emerge from work to maximize the common good (Fontana, 1999). 


\section{Methodology}

Dialectical hermeneutics is constituted in a philosophical tradition that became in the 2oth century a research methodology, otherwise useful when it comes to interpreting the symbols and signs that emerge from the relationship between texts and contexts to produce scientific knowledge that values, All other things being equal, the objective and subjective dimension of a reality. In the words of Moreno (2008), the exegetical action develops a dialogue between at least two different horizons: on the one hand, the one that comes from the tradition that identifies the questioned text as an understandable fragment of its time and space and; on the other, the horizon to which the interpreting subject belongs. Many times both horizons are very different, which is why in order to understand the message of a text, one must first understand its context of origin, from its own narrative logic.

On this occasion, each and every one of the sources collected and ordered under the research documentary design protocol, were re-read based on three specific criteria that were formulated in the questions:

1. What political and ideological interests does the questioned author defend?

2. In what way does the work in question reflect the great lines of thought of its time and space of origin?

3. What theoretical or practical utility do the revised ideas, categories or concepts acquire for today's world?

4. What function does Gramsci's theory give to the critical intellectual with social commitment immersed in a general context marked by the crisis of the current world order?

Therefore, with this methodological criterion, the hermeneutical circle advanced by us, as an intertextual dialogue that occurs between texts and different contexts, horizons and knowledge, was oriented to seek answers, even if they are partial, to each of these questions without any intention of arrive at definitive conclusions on the subject or provide knowledge with the claim of universality. Rather, it was a question of qualifying Gramsci's central ideas about intellectuals in order to strengthen at least theoretically, in today's world, the role of the critical intellectual, a bulwark that is certainly not the monopoly of any particular political tendency of the left or right, such as some radical populist speeches have pretended.

\section{Organic intellectuals in today's world}

Together with the questions formulated in the previous section, it was also investigated: $\dot{i}$ What specific ideas are salvageable from an approach 
Anatolii P. Getman, Danilyan Oleg G., Magda Julissa Rojas-Bahamón, Diego Felipe ArbeláezCampillo y Olexandra's Ptashnyk-Serediuk

that originated in a reality very different from that of today's world? How valid can a vision of intellectuals that arises within a philosophy anchored in historical reality have multiple totalitarian experiments in the 2oth century? And what characteristics would organic intellectuals have in today>s world? These and other similar questions will try to be answered in this section as a condition of possibility to solve the objective of the research and at the same time promote an academic debate that allows rethinking the organic intellectual establishment and, functional to the system, in the coordinates of the general crisis in full development.

To answer the first question, it is well to reiterate that some theories manage to transcend their epochal context for different reasons, ranging from the validity of their ideas to responding to current problems or because of their intrinsic ability to adapt - without losing their essence - to new ones. or renewed problems imposed by epistemological reflection and reality itself. As will be argued in this section, we believe that this is the case of Gramsci's theory of organic intellectuals, a prelude to all the postmodern planning of critical and counter-hegemonic thinking. In this order of ideas, at least concepts such as: organic intellectuals, traditional intellectuals, the historical bloc and civil society are salvageable, all in the Gramscian sense.

As for the second question, it is clear today that in many crucial respects the experiments of real socialism deviated from the original meaning of classical Marxism. Hence, the dictatorship of the proletariat, where it was implemented, was in practice the dictatorship of the one party to undermine social pluralism and, immediately afterwards, the dictatorship of the one party was really the dictatorship of a caudillo like Stalin or a clique. civic-military closed of the politburo of the communist party. In addition, it should be noted that for Gramsci the last stage of the organization of the classless society was the dissolution of the State, however, for obvious reasons this step was not promoted in practice by any Marxist socialist organization in the exercise of power.

Although many more phenomena of dissonance could be enunciated between the original Marxist proposal and what happened, for example, in China and the Soviet republics, the reality of the case is that in its essence Marxism suffers from a proper democratic theory (Sartori, 2009; 1988) seminal weakness that the first classical liberalism also possessed -, which does not mean that his contributions to the development of critical and counter-hegemonic thought have not been substantial to leverage later theories such as those formulated by the Frankfurt school, the liberation or Latin American critical philosophy, among others. Hence, even cataloging Marxism as a philosophy close to totalitarian traditions, the validity of many of its contributions, categories of analysis and particular concepts cannot be denied when it comes to explaining the schemes that produce and reproduce all forms of oppression In today's world. 
For its part, the third question, what characteristics would organic intellectuals have in today's world? It demands a more weighted response from the knowledge of the great socio-political and economic trends that define the foundations of the history of the current world, marked by the substantial increase in entropy and conflicts of all kinds in the framework of a transition process to a new order of uncertain content (Villasmil, 2020; Parra, 2020; Arbeláez-Campillo et al., 2019).

Indeed, if I had to summarize the major problems that will delimit political agendas at a global level, 5 themes would be tentatively pointed out because of their unusual transcendence and centrality, namely: a) the crisis of representation of contemporary polyarchies beyond the adjective of participatory democracy or grassroots democracy; b) the growing material and symbolic inequalities that relegate huge numbers of people to a life of violence, lack of opportunities to develop their life projects and precarious access to basic goods and services; c) the systematic deterioration of the biosphere throughout the planet due to global warming and the greenhouse effect; d) the international repositioning of authoritarian governments in the East and West that undermine human rights and, finally; e) the absence of a new philosophical system that leads to the emergence of a different political thought that manages to surpass - with novel proposals - the longestablished dichotomies of Marxism / liberalism, democracy / autocracy and planned economies / market economies, in order to achieve sustainable development on a planetary scale.

In this order of ideas, the two categories of intellectuals formulated by the author of the Prison Notebook, would find themselves again facing a bifurcated path between: adapting in an accommodative way to the requirements of the status quo, justifying their models, practices and representations, which would imply a traditional / functional intellectual stance or; on the contrary, to take up the banners of struggle of the organic intelligentsia as a condition of possibility to give answers, as a theoretician or entrepreneur ${ }^{7}$ in the face of resistance and social organization, to the great challenges imposed by today's world, challenges that translate into in multiple problems that constitute, without a doubt, forces contrary to democracy and the achievement of the good life for the majority.

For Jiménez et al., (2019), the organic intellectual in today's world is identified, in the psychological dimension of being and doing, by an attitudinal profile of an innovative leader who gallantly assumes the demands of the political, social and organizational environment in which it is immersed. In the same way, he is characterized by the display of three transversal qualities or skills in his life: critical thinking, critical behavior and dialogic attitude, consequently:

7 For an interesting work on the development of female entrepreneurship, it is recommended to consult (Pinkovetskaia et al., 2019) 
Anatolii P. Getman, Danilyan Oleg G., Magda Julissa Rojas-Bahamón, Diego Felipe ArbeláezCampillo y Olexandra's Ptashnyk-Serediuk

Their interrelation leads to the performance of leaders who are dissatisfied with their world, capable of identifying alternatives in the field of politics to advance in the rational transformation of the structures that support inequity. Their work will be consistent insofar as they involve the affected actors in the search for consensual solutions, for which they have the possibility of reaching agreements through a dialogical process of an intersubjective and rational nature that will not be exempt from contradictions and tensions (Jiménez et al., 2019: 54).

Again, it is interesting to note that the condition of organic intellectual and critical thinker is not exclusive to any particular ideological or partisan tendency, which is why critical thinking attitudes, wayward behavior contrary to dominant conventions and dialogical attitude can be observed. in the most dissimilar characters in the world of ideas that can be located in the ideological spectrum in positions: anarchists, eclectic, moderate or revolutionary, among others.

After the break with colonial ties, an arduous debate arises in Latin America, to define the national identity and at the same time determine the best formulas to order the independent territories and modernize their populations, in accordance with the parameters of the modernity program. politics, in its positivist stage of "order and progress" that tries to emulate the hegemonic societies of the West in the particular realities of the peoples of the South, without paying attention to their specificities, imbrications and miscegenations (multicultural and multiethnic).

In this sense, according to Villasmil and Jiménez (2015), it is common for nineteenth-century intellectuals to group as militants or sympathizers around the postulates of liberal or conservative parties, both with very particular national projects, which defended centralism and the Catholic confessional state, in the case of the conservatives - which will, in fact, be the dominant trend.

In the case of Colombia, for example, liberalism in general and the liberal party in particular, would be until the advent of progressive and postmodern ideas in the country, well into the twentieth century, the main symbolic referent that identifies the organic intelligentsia. According to Martín (2010), it was the Colombian liberals who rose up against the caudillo ideas of some sinister figures who designed custom constitutions to position themselves as life presidents and subject all public powers to their will; It was the Liberals who, while in power, decreed the manumission of the assets of the dead hands and, in this way, they advanced an additive reform that allowed to significantly increase the national agricultural frontier and; Furthermore, it was the liberals who fiercely and systematically defended the secular state model, freedom of worship, expression and thought as pillars of modernization. 
In the 21st century, pragmatism has gained ground and it is now the socalled technocratic intellectuals who seek to transcend left-right bipolarity from the tacit or open claim of neoliberalism, neo-conservatism or the third way. However, beyond their ideological camouflage, they are, in essence and existence, traditional / functional intellectuals because they seek to perpetuate the established order at all times and reduce its tensions or structural contradictions exclusively through reform, without ever posing a conducive debate. to the construction of a new model of society, more just and equitable for all.

As Uribe indicates: "The technocratic discourse is associated with the scientific one because it defends a society where those who make the decisions are the scientists or technical experts; these, in addition, support their positions through rational argumentation or critical thinking" (2016: 151). Seen this way, there is no problem in empowering experts in crucial areas of the economy or in the formulation of public policies whose purpose is to provide timely responses to the demands, aspirations and problems of the different communities that make up the national reality; The problem is that science is not, in any case, an ideologically neutral phenomenon; Therefore, in practice the technocratic groups in power have come to prop up a neoliberal agenda that cannot replace citizen intervention in the realization of participatory democracy, nor the collective deliberation of major issues of national interest.

As already mentioned in a previous paragraph, these are specialists, social communicators and experts in different areas who are interested in providing lights for the construction of a new or renewed model of a more just and inclusive society for all, in which, can combine development with social equity to build a sustainable socio-political and economic ecosystem over time; Hence, there are crucial differences between the organic intelligentsia - won to build a new social contract as a condition of possibility to overcome the vices and contradictions of this order of things - and the traditional ones, who seek their prolongation over time. The following table shows the most significant differences that exist between these two categories of intellectuals in the world. 
Anatolii P. Getman, Danilyan Oleg G., Magda Julissa Rojas-Bahamón, Diego Felipe ArbeláezCampillo y Olexandra's Ptashnyk-Serediuk

284 Rethinking the category of organic intellectual of/by Antonio Gramsci in today's world

\begin{tabular}{|c|c|c|c|c|}
\hline & $\begin{array}{l}\text { Political } \\
\text { and } \\
\text { ideological } \\
\text { interests }\end{array}$ & $\begin{array}{l}\text { Model of } \\
\text { economy } \\
\text { and society } \\
\text { that they } \\
\text { defend }\end{array}$ & $\begin{array}{l}\text { Social impact } \\
\text { of their } \\
\text { ideas }\end{array}$ & $\begin{array}{l}\text { In tune with } \\
\text { the great } \\
\text { problems of } \\
\text { the country } \\
\text { and the } \\
\text { world }\end{array}$ \\
\hline $\begin{array}{l}\text { Organic } \\
\text { Intellectuals }\end{array}$ & $\begin{array}{l}\text { Democratic, } \\
\text { inclusive, and } \\
\text { participatory } \\
\text { conception of } \\
\text { the exercise of } \\
\text { power. }\end{array}$ & $\begin{array}{l}\text { They } \\
\text { promote the } \\
\text { construction } \\
\text { of less } \\
\text { hierarchical } \\
\text { societies and } \\
\text { economies at } \\
\text { the service } \\
\text { of human } \\
\text { dignity } \\
\text { and the } \\
\text { ecosystem. }\end{array}$ & $\begin{array}{l}\text { They often } \\
\text { constitute } \\
\text { theorists } \\
\text { of various } \\
\text { political parties } \\
\text { and social } \\
\text { movements that } \\
\text { seek to promote } \\
\text { processes of } \\
\text { emancipation } \\
\text { of oppressed } \\
\text { and relegated } \\
\text { minorities. }\end{array}$ & $\begin{array}{l}\text { They are } \\
\text { usually the } \\
\text { interpreters } \\
\text { of the main } \\
\text { challenges } \\
\text { and problems } \\
\text { of their time } \\
\text { and social } \\
\text { space. } \\
\text { They are } \\
\text { usually the } \\
\text { interpreters } \\
\text { of the main } \\
\text { challenges } \\
\text { and problems } \\
\text { of their time } \\
\text { and social } \\
\text { space. }\end{array}$ \\
\hline $\begin{array}{l}\text { Traditional/ } \\
\text { functional } \\
\text { Intellectuals }\end{array}$ & $\begin{array}{l}\text { Procedural } \\
\text { visions of } \\
\text { democracy } \\
\text { are privileged } \\
\text { over the } \\
\text { substantive } \\
\text { conception } \\
\text { that advocates } \\
\text { reducing } \\
\text { socioeconomic } \\
\text { asymmetries. }\end{array}$ & $\begin{array}{l}\text { They defend } \\
\text { neoliberalism } \\
\text { and social } \\
\text { stratification, } \\
\text { as a synonym } \\
\text { for order and } \\
\text { prosperity. }\end{array}$ & $\begin{array}{l}\text { Many } \\
\text { traditional } \\
\text { intellectuals } \\
\text { are advisers to } \\
\text { neo-populist } \\
\text { or radical } \\
\text { populist leaders } \\
\text { who tend to } \\
\text { personalize } \\
\text { political } \\
\text { processes to } \\
\text { the detriment } \\
\text { of democratic } \\
\text { institutions. } \\
\text { This in addition } \\
\text { to being the } \\
\text { specialists and } \\
\text { technicians of } \\
\text { the prevailing } \\
\text { economic, } \\
\text { political and } \\
\text { communication } \\
\text { apparatus. }\end{array}$ & $\begin{array}{l}\text { Although } \\
\text { traditional } \\
\text { intellectuals } \\
\text { fully } \\
\text { understand } \\
\text { the great } \\
\text { problems of } \\
\text { their time and } \\
\text { space, they } \\
\text { often make } \\
\text { proposals } \\
\text { that retard } \\
\text { the necessary } \\
\text { historical } \\
\text { changes } \\
\text { through } \\
\text { gradualist } \\
\text { or reformist } \\
\text { solutions to } \\
\text { politics and } \\
\text { economics. }\end{array}$ \\
\hline
\end{tabular}

Table No. 1: Own elaboration based on the referenced literature and the objective of the research.

Although it could be argued that the reality of intellectual work is much more complex than the partial photography offered by the painting, everything indicates that at least roughly the differences between these two opposite ways of exercising the office of ideas are well represented, science 
and culture. Without a doubt, organic and traditional intellectuals are moved by the influence of different political and ideological interests.

In this vein, both intellectual estates have up to now defended different economic and social models. For organic intellectuals, the key is to build, materially and symbolically, a less hierarchical and stratified society, in which the great decisions of public interest are not only made by the usual alliance between the political and economic elites with their backs turned to the true national interest. Consequently, they have made an effort to promote economic experiences, such as the orange economy or the social market economy, among others, at the service of human dignity and of all forms of life in general that are now threatened by the systematic predation of their environment (Calvano, 2018; 2019).

For their part, traditional intellectuals continue to defend - until its ultimate consequences - the development of a market economy in accordance with the parameters of the World Bank, the International Monetary Fund and the Organization for Economic Cooperation and Development (OECD), under the assumption that the invisible hand of the market will bring order, prosperity and well-being to all communities and regions, regardless of the empirical evidence against it that it bets for the strengthening of the welfare state.

In this way, the impact of progressive and traditional ideas is also very different in collective representations and insocial imaginaries. In the first case, any attempt to move to a qualitatively higher phase of history implies the democratic transformation of its systems, hence, organic intellectuals often become theorists of various counter-hegemonic political parties and social movements that seek to promote processes of emancipation of minorities oppressed and relegated by the prevailing statu quo. In contrast, the traditional ones continue to act as specialists and technicians, without a critical conscience or a dialogic attitude, in the maintenance of the economic, political, educational and communicational apparatus of the state, even advising many neo-populist or radical populist leaders who tend to personalize political processes to the detriment of democratic institutions.

In this common thread, perhaps the most notable difference between the two categories of thinkers, this in the way they connect or tune into the great problems of the world today. Let us remember that for Gramsci (1967; 1986), the organic intellectual stands out for his role within the historical bloc, as a moral force that dares to challenge the hegemony of the ruling class and its control of civil society to propose new horizons and possibilities. But unlike the time of the illustrious Italian philosopher, nowadays there is no attempt to promote an armed revolution leading to the structuring of a socialist society, nothing would be further from the geopolitical reality of the 21st century world. 
Anatolii P. Getman, Danilyan Oleg G., Magda Julissa Rojas-Bahamón, Diego Felipe ArbeláezCampillo y Olexandra's Ptashnyk-Serediuk

Rather, it is about making people and communities aware of the central challenges of their time and space and, therefore, promoting places and moments of deliberative and grassroots democracy, for the empowerment of citizens, leading to the achievement of consensus necessary to implement the changes and corrections that cannot be postponed at the structural level. For their part, traditional intellectuals, while fully understanding the major problems of their context, often make proposals that delay the necessary historical changes through gradualist or reformist solutions to politics and economics, favoring the achievement of elites' dominance. in making binding decisions, beyond the democratic and liberal veneer of their proclamations and speeches for mass consumption.

\section{Conclusions}

When trying to examine the role of the critical intellectual with social commitment in the current complex context, marked by the systemic crisis of the current world order, a set of findings emerge that strengthen the perspective of Gramsci's thought. In the first place, he urges to defeat the pragmatism and the dominant pessimism about the impossibility of promoting sustainable political, economic and social changes that come to dignify life, without lies and demagogies that do not advance historical processes.

In this sense, it is the organic intellectuals, as Portelli (1978) points out, those who have the responsibility of maximizing the consciousness of civil society that resists - with or without knowledge of it - the hegemony of a determined historical bloc, the pair to reveal its possibilities of action and of fight that are allowed by the objective and subjective conditions in which it is immersed. Ultimately, it is about strengthening the autonomy of people in the self-determination of their worlds of life, within the framework of a new ethic-politics, which, without betting on the absolute equality typical of the totalitarian orders of yesteryear, tends to structure a new social contract in the face of the post-conflict.

Second, the crisis in the representation of the current polyarchists, which translates into the distrust of the majority in the face of the leaders of the day and the capacity of the institutions to satisfy the growing social demands, is not something that can be resolved within the political and epistemological limits of all existing models up to the present, a situation that has precisely driven the crisis of the current world order. Due to this circumstance of exhaustion of the ways of doing and thinking about politics, the creation of a new philosophical system by organic intellectuals with social commitment is urgent, which will take democracy out of its quagmire and definitively prevent the return of authoritarian forms to exercise power. 
Finally, the organic intellectuals, through rational arguments, critical thinking and a dialogic attitude - never through violence - are the first force in charge of demonstrating in each place and moment, the unfeasibility of the gradualist and reformist approaches of traditional intellectuals to confront to the challenges imposed by today's turbulent world; in addition to interpreting the needs and aspirations of justice and equity of the context that are part, to provide it with concrete political content in the face of the transforming action of reality. At this point Gramsci is still current.

\section{Bibliographic References}

ARBELÁEZ-CAMPILLO, Diego Felipe; ANDREYEVNA DUDAREVA, Marianna; ROJAS-BAHAMÓN, Magda Julissa. 2019. "Las pandemias como factor perturbador del orden geopolítico en el mundo globalizado" En: Cuestiones Políticas. Disponible en línea. En: https:// produccioncientificaluz.org/index.php/cuestiones/article/view/31528. Fecha de consulta: 16/04/2020.

ARBELÁEZ-CAMPILLO, Diego Felipe; ROJAS-BAHAMÓN, Magda Julissa. 2020. "Pandemics in globalization times" En: Amazonia Investiga. Vol. 9, No. 27. Disponible en línea. En: https://doi.org/10.34069/ $\mathrm{AI} / 2020.27 .03 .0$. Fecha de consulta: 20/11/2020

BLOG DEDICADO AL ESTUDIO DE CARLOS MARX. S/f. El "intelectual orgánico” en Gramsci. Una aproximación. Disponible en línea. En: https://kmarx.wordpress.com/2012/11/20/el-intelectual-organico-engramsci-una-aproximacion/. Fecha de consulta: 20/06/2020.

BOBBIO, Norberto. 1991. Estudios de la historia de la filosofía De Hobbes a Gramsci. Editorial debate. Madrid, España.

BUCI-GLUCKSMANN, Christine. 1978. Hacia una teoría materialista de la filosofía. Siglo veintiuno editores. Madrid, España.

CALVANO CABEZAS, Leonardo. 2018. Contrato social y modernidad política en Colombia. Fondo editorial de UNERMB/ Universidad del Zulia. Cabimas, Venezuela.

CALVANO CABEZAS, Leonardo. 2019. "Apuntes sobre los Desafíos que entraña el Nuevo Contrato social para Colombia en Tiempos del Postconflicto" En: Cuestiones políticas, Vol. 36, No. 63, pp. 14-29.

DÍAZ-SALAZAR, Rafael. 1991. El proyecto de Gramsci. Antrhopos editorial del hombre. Barcelona, España. 
Anatolii P. Getman, Danilyan Oleg G., Magda Julissa Rojas-Bahamón, Diego Felipe ArbeláezCampillo y Olexandra's Ptashnyk-Serediuk

288

Rethinking the category of organic intellectual of/by Antonio Gramsci in today's world

DUSSEL, Enrique. 2001. Hacia una filosofía política crítica. Desclée. Bilbao, España.

FIORI, Giuseppe. 1976. Vida de Antonio Gramsci. Ediciones península. Barcelona, España.

FONTANA, Josep. 1999. Historia: análisis de la realidad y proyecto social. Biblioteca de bolsillo. Barcelona, España.

GONZÁLEZ, Fernán. 2014. Poder y Violencia en Colombia. ODECOFI-CINEP. Bogotá, Colombia.

GRAMSCI, Antonio. 1967. La formación de los intelectuales. Editori Riuniti. México DF., México.

GRAMSCI, Antonio. 1986. Cuadernos de la cárcel Edición crítica del Instituto Gramsci a cargo de Valentino Gerratana (cuatro tomos). Ediciones era. México DF., México.

JIMÉNEZ IDROVO, Ítalo Vinicio; FERNÁNDEZ ESPINOSA, Cira; SÁNCHEZ PADILLA, Yadira Liliana. 2019. "Perfil actitudinal delíderes innovadores: Una mirada desde la psicología política“"En: Revista de Ciencias Sociales. Vol. XXV, No. 3, julio-septiembre, pp. 1315-9518.

MANSILLA, H.C.F. 2002. "Intelectuales y política en América Latina Breve aproximación a una ambivalencia fundamental" En: Espacio Abierto. Vol. 11, No. 3, julio-septiembre, pp. 429-454.

MARTÍN, Américo. 2010. La violencia en Colombia. Los Libros de el nacional. Caracas, Venezuela.

MORENO OMEDO, Alejandro. 2008. El aro y la trama Episteme, modernidad y pueblo. Convivium. Miami, EUA.

PARRA CONTRERAS, Reyber Antonio. 2020. "Una perspectiva del mundo que se nos avecina" En: Revista de la Universidad del Zulia. Disponible en línea. En: https://www.produccioncientificaluz.org/index.php/rluz/ article/view/31532/32613. Fecha de consulta: 22/06/2020.

PINKOVETSKAIA, Iuliia; ARBELÁEZ CAMPILLO, Diego Felipe; ROJAS BAHAMÓN, Magda Julissa; GROMOVA, Tatiana; NIKITINA, Irina. 2019. "Female entrepreneurship development in the Russian Federation" En: Amazonia Investiga, Vol. 8 No. 18, enero-febrero, pp. 111-118.

PORTELLI, Hugues. 1978. Gramsci y el bloque histórico. Siglo veintiuno editores, Bogotá, Colombia. 
RUBIANO MUÑOZ, Rafael. 2007. Derecho y Política Miguel Antonio Caro y la regeneración Miguel Antonio Caro y la regeneración Miguel Antonio Caro y la regeneración en Colombia a finales del siglo XIX. En: Opinión Jurídica Opinión Jurídica - Universidad de Medellín. Vol. 6, No. 12, pp. 141-162.

SARTORI, Giovanni. 1988. Teoría de la democracia 2. Los problemas clásicos. Alianza universitaria. Madrid, España.

SARTORI, Giovanni. 2009. La democracia en 30 lecciones. Taurus. Bogotá, Colombia.

URIBE, Catalina. 2015. El discurso político de los tecnócratas Un análisis de la comunicación de gobierno de Juan Manuel Santo. En: De Uribe, Santos y otras especies políticas Comunicación de gobierno en Colombia, Argentina y Brasil. Universidad de los Andes. Bogotá, Colombia.

VILLASMIL ESPINOZA, Jorge Jesús. 2020. "La fragilidad de las civilizaciones humanas" En: Cuestiones Políticas. Disponible en línea. En: https://doi. org/10.46398/cuestpol.3764.00. Fecha de consulta: 20/06/2020.

VILLASMIL ESPINOZA, Jorge; JIMÉNEZ IDROVO, Ítalo. 2015. El discurso de la unidad americana en tres tiempos: independencia, organización nacional, antiimperialismo. Universidad de Machala. Machala, Ecuador. 
ISSN 0798-1406 Depósito legal pp 198502ZU132

\section{Cuestiones Políticas}

\section{Planilla de suscripción}

Nombre

Institución

Dirección

Ciudad País

Cheque de gerencia a nombre de: Universidad del Zulia (LUZ),

Facultad de Ciencias Jurídicas y Políticas, Ingresos Propios

Banco Occidental de Descuento, Cuenta corriente № 212700890-9

Tarifa de suscripción por un año (dos números):

Venezuela: Bs. 80 + Envío

Ejemplar solo: Bs. $40+$ Envío

América Latina \$ $40+$ Envío

Resto del mundo $\$ 50+$ Envío

Esta planilla debe ser enviada a la siguiente dirección:

Revista "Cuestiones Políticas"

Facultad de Ciencias Jurídicas y Políticas

Instituto de Estudios Políticos y Derecho Público

Apartado Postal 526, Maracaibo Venezuela

Puede adelantar información por: cuestionespoliticas@gmail.com

loichirinosportillo@gmail.com 